Original Research

\title{
Understanding Education Decentralization and 'Sustained' Elite Capture - Explicating Cases From Two Public Schools
}

\author{
Sanjay Hamal* \\ Kathmandu University School of Education, Lalitpur, Nepal
}

\begin{abstract}
The paper aims at uncovering the practices of educational decentralizationin Nepalthat started after the restoration of democracy in 1990. Though decentralization in education in Nepal began with the aim of greater community participation and autonomy to the needs and priorities perceived by the local level functionaries in school, it has been subject to elite capture in its governance. Because of control in planning, organization, management, financial liability and different activities for the education system, the paper argues that practices of educational decentralization have been shaped by the local elites who capture the local resources and power to operate the school with their network and 'one-upmanship'. While arguing so, the paper is based on the ethnographic case study of two public schools located in the Mid-Western region of Nepal. Applying the Gramscian concept of hegemony, the paper narrates the process of a 'sustained' selection of the School Management Committee Chairpersons and shows how they negotiate and balance their power to sustain their capture. The paper concludes that the informal mechanisms of individual attributes such as trust and capital are playing an important role in their sustained elitism.
\end{abstract}

Keywords: Decentralization; elite capture; hegemony; capital; trust

\section{Introduction}

Decentralization in its simplistic meaning is a transfer of authority from the central to the local government. However, in the process of decentralization, the 'degree of authority transfer' and the 'nature of decentralization' differ considerably concerning the level

*Author Email: phd.sanjayhamal@gmail.com

ISSN: 2091-0118(Print)/2091-2560(Online)

(C) 2018 The Author(s).

Published by Kathmandu University School of Education, Lalitpur, Nepal.

This open access article is distributed under a Creative Commons Attribution (CC BY-SA 4.0) license. 
to which the authority is transferred; the degree of autonomy that is devolved; and the elements of the system to decentralize (Fiske, 1996). Thus, decentralization strategies and approaches can take 'deconcentration, delegation and devolution' either of the forms, in which the deconcentration involves transfer of tasks and work, but no authority; delegation is a transfer of authority which is subject to withdrawal at the discretion of the delegating unit; and devolution is an independent exercise of transfer of authority.

Decentralization, as a public administration reform, after the 1970s have been widely adopted by different countries to improve the manner of delivery of social services and accounting for government expenditures and also the change in government structures (of governance) (Tolofari, 2005, p.75). Decentralization, thus, is a focus of attention, process and strategies for governments to improve public sector performance in ways that enhance citizen well-being. Decentralization and local service provision, undoubtedly, turn to decentralization's effects on many aspects of the public domain such as health, education, anti-poverty programmes, etc. Decentralization in education, for instance, calls for the local management of schools along managerial lines, the choice and powers given to parents and governors concerning the distribution and use of resources (Zajda \& Gamage, 2009, p. 15), on a presumption that local actors are better equipped to make appropriate decisions for their local context and better able to hold local actors accountable (Edwards, 2011, p. 69) to increase both the productivity and efficiency of educational delivery systems.

Decentralization in education, though, is seen as a strategy to encourage community participation in school management and, in turn, improving the quality and legitimacy of public schools (Rondinelli, 1981, as cited in Bhatta, 2009, p. 152); resulting in increased efficiency, greater accountability and equity, and more democratic decision-making processes (Edwards, 2011, p. 67), there has been scepticism about its effectiveness or its relevance as leverage to change governance practices (Prinsen \& Titeca, 2008, p. 149) Decentralization process, instead of devolution of authority and responsibility to make physical, administrative and financial decisions by the schools on their needs and priorities perceived by the local level functionaries in school, has been subject to elite capture in its governance "where elites take control of decentralized policies and resources" (Prinsen \& Titeca, 2008, p. 149) and vis-à-vis the school governance system also seems handicapped in the hands of local elites.

Thus, in the present article, I intend to explore the phenomenon of 'elite capture'by taking two schools as case examples. However, the main aim of this article is to explore the reason forthe 'prolonged elite capture' of an individual, often resulting in a lifelong fiefdom of 'one-upmanship'. This article primarily explicates the reason of how a particular individual (SMC Chair) can sustain and/or retain his chairmanship for an extended period. And to elucidate the term 'capture', I take refuge of Darrow and Tomas (2005), who state capture as the process by which elites ... define policies in a way that protects their interest (Darrow \& Tomas, 2005) or what Edwards (2011) states it as "a process by which unintended stakeholders emerge to mobilize policy reforms in their own favour" (p. 68). The elites are seen as mediators of power relations and influencing the process of school governance (Inbanathan, 2000). This power relations and the entire influencing process arenot always subject to and directed by policy reforms, rather, I observed the school governance processes are influenced and guided by various aspects such as ones' negotiating capability, bargaining power within and outside his/her community, individual capital and so on. Borrowing from Fox (1994), I call this informal influencing process a 'clientelism'. This relation of patronage, though a political concept, is informal and sustained via a pervasive exchange of material benefits for political voice (Fox, 1994). Thus, in this paper, by taking governments' initiative to decentralize school governance, intend to show how decentralization policies have become prone to elite capture on the one hand, and on the other hand, by exploring the relation of patronage as observed in the field study, I dig out the phenomenon of sustained 'one-upmanship'.

To organize the article, in the following sections I pose my methodological ground followed by conceptualizing education decentralization. The next section of the article focuses on the process of education decentralization in Nepali context and seeks to understand why and how decentralizing education has become prone to elite capture. In a scenario where implications of decentralization effort of the government along with development partners like World Bank (WB) has been critically questioned by different authors (Carney \& Bista 2009; Carney, Bista, \& Agergaard, 2007; Edwards, 2011;

Khanal, 2010), it becomes imperative to understand the repercussion of such reforms. The subsequent section is devoted to exploring the reason behind the perpetuation of such capture by considering field data. Exploring the dynamics behind such 'prolonged capture', often resulting in the lifelong fiefdom of 'one-upmanship' of an individual, is the central theme of this article. The final section is a conclusion with implications for further study.

\section{Methodology of the Study}

To explore the sustained 'one-upmanship' practice of elite capture, I had selected two schools namely Sarada Secondary School and Muna Secondary School ${ }^{1}$. Both schools were established in the 1970s. This article is a product of my field visit that I had carried out in the winter of 2016 for my doctoral thesis. I had purposefully selected these schools because of two reasons: first both the schools carry a history of four decades and second both the schools are exemplified as better-performing schools in regards to Secondary Education Examination (SEE) results. However, during my field visit, I had observed the School Management Committee (SMC) Chairpersons holding their positions for an extended period. Their prolonged stay in the office aroused my interest in exploring the dynamics behind the perpetuation of their stay which made me select these particular schools for my study. The study employed the interview(s) and observational techniques to collect data 
from different stakeholders. School Management Committee Chairs, the Head Teachers (HTs) of both school, teachers and guardians were the primary interviewee for this study with whom I had been in constant touch in regular intervals since the inception of my fieldwork. The interviews were conducted in Nepali and Tharu language (because of the dominance of Tharu inhabitants) and the voices were recorded on a recorder to grasp the originality of their sayings. The interview(s), both Nepali and Tharu, were later translated into English in the best possible way of researcher's knowledge and understanding. This piece of writing is one aspect of my empirical representation from the large set of data that I had gathered during my field stay.

\section{Education Decentralization: Meaning and Concepts}

Educational decentralization began with the basic premise that decisions made at the local level are quicker, informed, flexible and responsive to specific needs than decisions made at the center. Thus, educational decentralization policies, which a vertical transfer of power/authority to the local level, assumes increased efficiency, flexibility, accountability, and responsiveness at the local level, and is adopted largely to reform the education system. However, the debate of educational decentralization has gone pass beyond its simplistic meaning of 'deconcentration, delegation and devolution'. Along with its effect in equity; educational improvement; administrative and financial efficiency (Fiske, 1996), the debate of educational decentralization has taken its shift toward privatization ${ }^{2}$ and marketization ${ }^{3}$. Nevertheless, privatization and marketization are seen as a strategy of decentralization process (Mok, 1999) itself, because privatization to a large extent reduces state authority over schools, in terms of function and operation, because of a poor offering of goods and services by the government. Apparently, this shift of social service (i.e. education) from the state to the private sector and a belief that privatization and marketization will increase efficiency and will automatically achieve the universally desired outcomes are connected with the neo-liberal ideology (Apple, 2000), which I see as market-driven privatization and decentralization in education.

At one end, educational decentralization is associated with efficiency, accountability, being proactive to recognizing one's needs; Weiler (1990) contradicts the most common argument, as he puts forth: 'redistributing power, enhancing efficiency, and improving learning', of education decentralization (Weiler, 1990) by arguing that governments decentralize their educational systems to better manage conflict, rather than to reduce rigidity or improve effectiveness and efficiency. Likewise, authors like Eaton, Kaiser and Smoke (2010) argue, from a political-economy perspective, that governments do not undertake decentralization reforms to enhance efficiency and accountability, they do so to promote complex and varied political agendas (Eaton et al., 2010). Whatever be the arguments put forth by different authors, my notion of decentralization in this article relates to the kind of power that is decentralized (i.e. deconcentration, delegation, and devolution).
Thus, to explicate educational decentralization in relevance to my study context, I refer it as the process of delegating or devolving authority and responsibility by the central government to the local schools.

\section{Education Decentralization and Elite Capture in Nepal}

Education decentralization is not a new strategy for Nepal, but rather, one that has played an ongoing role in the national policy discourse since the arrival of modern, political, economic and social institutions along with the establishment of democracy in the 1950s (Edwards, 2011, p. 72). The advent of a new 'democratic' atmosphere in the post1950 circumstances resulted in the proliferation of schools and educational institutions. The country even endorsed a comprehensive reform in education in 1956 in the wake of newly emerged democracy. These reforms were aimed at increasing public access to education and communities were highly encouraged to participate in the foundation, management, and growth of public schools.

However, in the year 1961, the then King sacked democratically elected government and banned political parties. Consequently, the party-less Panchayat ${ }^{4}$ system was introduced. Markedly to accord with the changed political context, the Panchayat government introduced reform in 1971 with the introduction of National Education Systemic Plan. The ultimate goal of this reform was aimed at producing citizens faithful not only to the country but also to the Crown who would conduct themselves following the Panchayat system. The Panchayat goals were pursued in a very centralized and regulated manner; thus, the government took over the authorities of school management from the local community as envisioned previously.

The restoration of democracy in 1990 saw decentralized school governance in an ardently new avatar. The promulgation of Local Self Governance Act (LSGA) in 1999 (His Majesty's Government of Nepal, 1999) was one of the first moves of the government towards decentralization-related reforms. The LSGA had envisioned community-based management (i.e. the system of managing, implementing, supervising, monitoring, and evaluating education at the local level). However, a breakthrough in the actual practice of decentralization in public schools came along with the seventh amendment of Education Act (1971) in the year 2002 (His Majesty's Government of Nepal, 2002). The amendment paved the way for greater reform in school education by giving substantial authority to local bodies, School Management Committee (SMC), and civil society. It was for the first time, the primacy of the SMCs over local elected bodies, the Village Development Committee (VDCs), District Development Committee (DDCs) and municipalities was enshrined in the legislation. Unlike the LSGA where local bodies were responsible for the growth and development of schools, the amendment vested SMCs with executive powers for the improvement of schools. The formation of SMCs was also devolved to the parents where they could elect the candidate of their choice in contrast to the previous provision

Journal of Education and Research, Vol. 8, No. 1, 2018 
where the District Education Office (DEO) would nominate the SMC Chairpersons. The SMCs, however, remained under the jurisdiction of the DEO

Along with the government initiatives, assistance from donor agencies to assist Nepal's education decentralization process also came into the forefront. However, it is often argued that the concepts of decentralization, improved school management, privatization, and outcomes-based curriculum reforms have "largely come from Northern, often World Bank, ideologies" (Watson 2000, p. 140). Nevertheless, in Nepal, amongst the multitude of possible ways to decentralize educational services, the notion formed around the role of local communities: "Community participation was emphasized..." (Carney \& Bista, 2009 , p. 201). The terms such as 'autonomy', 'responsibility', 'ownership', and 'local' gave a particular form to international discourses concerned with decentralization. Thus, along with the assistance of donor agencies and in a changing political environment, new policy approaches such as 'decentralization', 'community empowerment' and 'inclusive democracy' were put forth.

However, the education decentralization effort in Nepal has been in a disjuncture between what is advocated and what is in reality. For instance, Parajuli (2007) states that decentralization efforts have merely been a slogan to divert public attention from issues like the legitimacy of power, corruption, etc. Because of the state control in "planning, organization, management, financial liability and different activities for the education system" (Parajuli, 2007), community participation was sought only in limited and petty things like physical facilities, or daily management of schools and nothing in key aspects like curriculum, assessment, teacher management, etc. Likewise, no evidence of the inclusiveness and ownership of school because of the donor-driven ideology; contentious issue of power-sharing between the major interest groups of the country; deep-rooted bureaucratic culture; reforms formulated and implemented via a highly centralized policy; the tradition of power monopolization by top-level officials (Carney et al., 2007; Khanal, 2010 ) etc. are the reasons to name a few as to why the experience of nationalizing and transferring of schools to community was considered a setback. Similarly, Edwards (2011) also states that because of the policy disconnect in Nepal, decentralization never reached parents. Through an example of the process of information dissemination from the District Education Office(r) (DEO) to the schools, the author portrays the nuances of decentralizing policies and shows how they affect the entire decentralization process. The transitory and political nature of the DEO position, alliance with the local elite and the (un)willingness to disseminate information by the DEO have been subtly explained by the author for the setback of decentralization efforts. Also, despite the rhetoric of cooperation and partnership in education reforms from the international agencies, especially in the discourse of privatization and decentralization of schooling, in reality, economic and political pressures and policies are keeping many developing countries in the state of symbiotic dependency (Zajda, 2006, p. 17).

Journal of Education and Research, Vol. 8, No. 1, 2018
Thus, from the above instances, I argue that government initiative to transfer ownership of schools to local community did not yield much fruits in meeting state's goal of improving the governance of schools mainly, "because of the lack of institutionalization of these initiatives and also because of the lack of capacity building exercise at the lower level" (Research Center for Education Innovation and Development, 2009). On the contrary, it provided an opportunity for local elites to capture or 'play with the rules of the game' of school governance where local elites "capture the distribution of resources, project implementation and decision making which negatively impacts non-elites or the target population or is deemed to be corrupt under the law" (Musgrave \& Wong, 2016, p. 92). When decentralization is limited only into policy papers and not into process and culture (Khanal, 2010), "structures of local accountability tend to be weak and decentralization does not fulfil its potential for more efficient and effective delivery of public services or more accountable and democratic local governance and in contrary local governments are at the mercy of local elites" (Palaniswamy \& Krishnan, 2012, p. 449). This sort of fragile stage makes a fertile ground for elite capture where a few, usually politically and/ or economically powerful groups, usurp resources transferred for the benefit of the masses, at the expense of the less economically and/or politically influential groups (Dutta, 2009, p. 3). Apparently, in decentralized governance scenario, "the position of national elites is weakened and thereby local elites may capture decentralized public services and escape the control of the national state" (Prinsen \& Titeca, 2008, p. 28). Moreover, one can argue that in a fledgling democracy as in Nepal where there is a long absence of elected local government ${ }^{5}$, this has further strongly reinforced local elites to get a handle on their subject and their environment (Prinsen \& Titeca, 2008) making decentralization policies "ever-evolving networks of patrons and clients, rather than a genuine reform of the public administration" (Prinsen \& Titeca, 2008).

\section{Elite Capture in Selected School: Evidence From the Field}

The concept of 'elites' is based on the notion that every society holds a ruling minority, a group (or a person) that controls and disputes the most important power sources (López, 2013 , p. 1). The classical elite literature defines elites through capacity, personality and skill. For instance, Pareto (1935) distinguished elites between those who resembled the lion (domination by force) and those who resembled the fox (domination by persuasion and skill). The contemporary elite theories, based on the core of classical elitism, also define elites' as actors controlling resources, occupying key positions and relating through power networks (Yamokoski \& Dubrow, 2008). Thus, the state-of-the-art concept of elites is more closely related to the Weberian notion of power, understood as the capability of implementing one's will, even against the will of others (Weber, 2005, as cited in López, 2013 , p. 3) that usually enjoy important advantages (Higley, 2010, p. 161) and are capable of shaping political and social outcomes. 
The present study, however, largely depicts a 'paradoxical' situation of the established notion of elite capture. The elite capture which is seen as a process whereby the resource transferred designated for the benefit of the larger population is usurped by a few individuals of superior status; the study also observed "'inverted capture' where the communities/committees try to capture the elite and not only the other way around" (Prinsen \& Titeca, 2008, p. 159). Considering resource generation capacity of SMC Chair as a case example, the study noted enforced request from the community members and/or the guardians for the same persons to prolong their tenure. Recalling an incident of how the SMC Chair of Sarada Secondary School was able to get funds for the school, one guardian stated:

We need a capable person as SMC chair. Capable in a sense that who can bring resource and other education related materials for the school. You see, we did not have separate toilets for girls and this was creating discomfort and was detected as a prime reason for absenteeism among girl students during the time of menstruation. We tried to get funds from the DEO but were unable to do because of the budget shortage. The Chair's genuine effort was able to bring the funds from JICA to build these toilets.

Building toilets had two advantages: it reduced girls' absenteeism on one hand and on the other hand, the parents of poor kids got employment during the building of toilets.

The capability of generating funds, in one way or other, was a primary reason for the School Management Committee or the guardian's desire to retain the particular person as a chair. I argue this tendency of guardians has strengthened their fiefdom unanimously. The study discovered both the presidents had almost two decades of presidency term despite small interruptions in their tenure. The Chairperson of Sarada Secondary School had to leave the office for three years in his twenty-five years term because of the policy change where only the guardians could be the SMC president. Again, after the change of policy, with no restriction for the criteria of SMC Chair as such 'only' guardians could become the Chair, the same person was (re)selected and has been holding the office since then. Similarly, the Chairperson of Muna Secondary School has also been holding his position since the inception of the school. Though he had to leave his position during the time of conflict $^{6}$, when he was threatened for his life, after the comprehensive peace accord signed between the then insurgents and the government back in 2006, he has been retaining his office.

During my stay in the field, I observed the SMC Chair (e.g. of Sarada Secondary) dutifully complying with the commands or instructions of their authority in their intention to make expenditures public. Though the government has introduced the concept and policy of social audit as mandatory in all community schools since 2005 and a legal binding was first incorporated in the Education Regulation, 2002 (3rd amendment) (Department of Education, 2008), which is mandatory for the release of school funds, the school submitted a social audit not only with the intention of accessing funds from the District Education Office but also as a genuine effort to keep stakeholders informed about the incomeexpenses. One guardian as below recites the dutifulness of the SMC Chair:

The Chairman always calls for a meeting when any decision regarding the school is to be made. Even if we do not have time to attend the meeting for any reason that particular day, the meeting is cancelled and is scheduled for the next day when most of us are available. He has been the Chairperson since the inception of the school so he takes care of the school to his level best. You see, financial details are also made public and discussed in meetings. Moreover, because of his political ties he can bring necessary resources to school. This is the reason we select him unanimously every year.

While in the field, I even observed that parents had no disapprobation in selecting the same person as long as they were working for the betterment of the school. In retrospect, one of the guardians from Muna Secondary School recited the genesis of the school and the contribution the incumbent chairperson has made to bring the school into its current shape. He stated,

I remember the school had opened as an informal gathering for the backward and poor Tharu community children under the chairmanship of the incumbent Chairperson. The school was established to educate children from poor and backward Tharu community. The school was initially run in the evening time so the children could attend school after their days' work. Because of its off-hour operation and attendance of more than ninetyfive percent Tharu children, the school was called 'Night Tharu School'. Later on, the school got its name under a local philanthropist, who had donated a handsome amount for the construction and renovation of school buildings. You know, the chairperson is the one who had done all the hard work to bring new life to school.

When asked about the holding of office for a prolonged period, guardians from both schools had a similar line of voice:

During the time of transition and weak or no local elected representative, there is a need for one-upmanship that provides stability and trust towards each other rather than frequently changing leadership'. The retention of the same individual was not perceived as the perpetuation of one-upmanship and elite capture, but it was reiterated 'as effective and efficient leadership, capable of performing and serving the school better by bringing resources to the school'. The unanimous selection and continuation of the same person was also seen as 'reducing the annoying and expensive way of choosing (rather than going into the election) the SMC president both in terms of time and effort.

The voice of one guardian echoes:

Even if we have an election for the SMC Chairperson, we select the same person. Why waste schools' resources for nothing! Moreover, we select him because he has done a lot 
for the school and community. I remember, last year, when the budget was not released for making our roads paved despite being allocated, he was the one who fought for it and finally got the budget released. Now we have paved roads in the neighbourhood.

Thus, the study shows that it was not 'that' particular individual who would always try to capture the schools; it was also the school who would continuously try to select such person who could 'at least' do things for the betterment of the school.

Nevertheless, my in-depth interviews with the SMC Chairs discovered their altruistic nature was not truly altruistic. I excavated both the SMC Chairs even had a desire to stay as the Chair, though not for economic advantage, but to secure their social/political status intact. I observed they also had implicit desire to continue their tenure as a chairperson which in other way perpetuated their political influence over the community and it was thus like a social stigma for them. As both the chairperson stated during their interview:

If we hold a position, it will increase my bargaining power with the higher authorities.

This will also assist us in bringing resources and in most cases reverting decision in our favour.

It was because of their political influence both chairpersons had multiple affiliationsto various organizations like Drinking Water Committee, Chairmanship in Eye Hospital, membership in different Cooperatives etcetera. And I see their multiple affiliation contributing to their political influence.

The above illustrations assert elite capture as an inevitable phenomenon in the selected school, in one way or other, if not for the economic benefit but for the political advantage. However, the main quest of this study is to explore the sustained one-upmanship and the reason behind it. The following section explains in detail, the dynamics of one-upmanship from the selected schools.

\section{Perpetuation of One-upmanship: Experience From the Field}

In both the schools, the SMC Chairs had been associated with their respective schools since the start of the school back from 1977 and 1978 for Sarada and Muna Secondary Schoolrespectively, expect few years in between when they were not able to remain as Chair because of the provision that only the guardians could be the SMC Chair. The question that germinates out of this phenomenon is that how have both the Chairs been able to hold their respective offices years after years. Is it because of their involvement in the schools since their inception? What reasons were there that helped them to sustain in their respective offices? The following section is an exploration of such sustained one-upmanship in the selected schools which is also the key quest of the paper.

\section{Hegemony: Capital, Trust, Political Ties and Bargaining Power}

Hegemony has been defined as "the process of moral, philosophical, and political leadership that a social group attains only with the active consent of the other important social groups" (Artz \& Murphy, 2000, p. 1). Thus, hegemony is the system of power that has the support of the subordinate. But power does not arise naturally. Power often relies on physical force, economic constraint, legal guidelines or other coercive techniques (Artz $\&$ Murphy, 2000, p. 2). And from the Gramscian perspective, power is exercised through a fluid combination of coercion, passive acceptance, and active agreement, and the ability of social groups to attain a position of moral and intellectual leadership (Ambrosio, 2013, p. 317). With my field experience, I argue that rather than exercising coercive power to retain/ sustain their chairmanship, both the chairpersons had won communal trust through active civic engagement and their social capital. I observed both the chairpersons had in mind that coercion could be expensive and dangerous for them which would result in revolt against their chairmanship (i.e., selection of another candidate). As an alternative to coercive action, the SMC Chairs had negotiated their hegemony via capital, trust, political ties and bargaining power.

I see the capital of the SMC Chairs as one hegemonic element of their sustained elitism. Capital is a 'resource' that can assume monetary and nonmonetary as well as tangible and intangible forms. I take the Putnamian (1995) concept of 'capital' in relevance to my study purpose. The Putmanian (1995) concept of social capital has three dimensions: moral obligations and norms, social values (especially trust) and social networks (especially voluntary associations). Though Putman's social capital has its base on 'well-functioning economic system', and 'high level of political integration', his emphasis on social capital is based on consensus and interconnected networks of trust - among citizens, families, voluntary organizations, religious denominations, civic associations, and the like (Putman, 1995).

Because of the multiple (non)voluntary association of the SMC Chairs in various social, private/public and religious organization, within and outside their community, their horizon of networks had outreaching consequences, which had strengthened their social capital which in turn had helped them to hold their respective offices. How did this social capital form then? The formation of social capital was not a one-day phenomenon, it was the result of the accumulation of their persistent involvement in civic activities in the community which in turn had bestowed them with community trust.

The SMC Chair's contribution to bring this school to the current shape is unmatchable. His relentless efforts since the demise of founding principal Ram Lautan Chaudhary is simply beyond expectation. His persistent and passionate effort has not only seen this school grow from primary to graduate school but also it has been one of the good results producing academic institutions in the area. Under his mentorship, the school 
got higher secondary approval and also got Graduate programs (science, humanities, education and management). As such, the needy and aspiring students did not have to go outside to complete their studies, at least graduation. (A veteran teacher from Sarada Secondary School).

Likewise adding to the civic contribution of the Chairperson from Muna Secondary School, a guardian states,

Our SMC Chair's major contribution is in initiating the construction of a water tank for the safe drinking water. Before piped drinking water, we had hand pumps. When he heard the reports of a high level of arsenic in drinking water, he was the one to tie his belt for shuddering the Town Development Committee to build the reserve tank. See now we have piped drinking water $24 X 7$. Because of his numerous other voluntary social work, people have faith in him and usually go hand in hand with him whenever he says something.

Thus, as Putnam (1995) states, I argue that trust upon the SMC Chairs has been created by their working for the communities in social activities, this, in turn, has developed 'sustained' trust and reciprocity for the Chairpersons. As Macharia (1997) notes, trust leads to the formation of social networks and later translates into social capital. Trust is an issue that builds up over time through frequent interactions, and reciprocal relationships (Coleman, 1998; Radaev, 2002, as cited in Odera, 2013, p. 132). Individual actors do something for the general good not because they know other interactors but because they trust that their own action will be "rewarded" via the positive development of communal relations (Newton, 1999, p. 8). Trust creates the basis for brave reciprocity, and "social networks and associations that are not means for realizing the short-term interests of any specific individual or groups, rather trust creates reciprocity and voluntary associations, reciprocity and associations strengthen and produce trust" (Putnam, 1993). The forms of social capital are self-reinforcing and cumulative by nature. As Coleman (1988) states, the more social capital is used, the more it grows.

The Sarada Secondary School Chairperson was able to construct a two-storey building with the help of local labourers. The event of the building of that particular block was reminisced by one guardian as:

We had only approximately eighty percent of the estimated amount to construct the building. The Chairman, however, was not disheartened of the inadequate amount. His wider political and social network made it possible to erect the building. We managed to get some donation from JICA and local philanthropist but still the labour-charge cost was insufficient. The president then appealed for voluntary toil within and outside the community. It was because of his wider socio-political connections and also, I guess because of the moral obligation for a noble cause, people poured in and the construction was possible. This way the building was erected without having to pay for the labour.

It was because of their prolonged civic engagement and effort of the SMC Chairs to do better for schools, they had developed a trust among the community members. This goodwill was reciprocated to them in their unanimous s(election) in School Management Committee elections. The election was merely a formality (as I have stated above) for any resistance that could arise but with no or little chances and to follow the norms but in almost all occasion the selection was done without dissent. It was that group or/an individual, who had civic engagement, networks and political influence, social capital and bargaining power, who drove and sustained hold in the school and the schools on the other hand also held the type of individual who possess these attributes.

From the field evidence, I can thus state that the continuation of one-upmanship is strengthened by one's capacity to improve the school infrastructure by soliciting donations, in cash or kind. As stated earlier, both the SMC Chairpersons had inter/intra linkages, and bargaining power within/among different institutions that are within or beyond their jurisdictions. As Palaniswaym and Krishnan (2012) state, this bargaining process is critical to the resource allocation and is embedded in local lower hierarchies (p. 452)

\section{Conclusions}

This article focused on the latent elements that come along with decentralized education policy, 'elite capture' for instance. However, I argued rather than being latent, these informal mechanisms resulting in the capture, as such, continues to be ubiquitous and influential. The study shows an informal mechanism of social networks and trust playing a central role in school governance. These dynamics of informal mechanism also tend to draw their legitimacy through the long-standing practice as no other actors seem to challenge the authority. Thus, the phenomenon of elite capture via informal mechanisms are such crucial aspects which need to be examined in the educational decentralization context in Nepal. Though elite capture is taken as 'evil' as stated in most of the literature (Dutta, 2009; Mattingly, 2016), the study found positive impact resulting in better outcomes in terms of resource generation for the selected schools. 'Trust', 'political ties' and 'capital' of an individual and the way they are exercised seem to have played a dominant role in the continuation of the prolonged one-upmanship in the selected schools and these characteristics of a person have contributed to the 'inverted capture' as well.

\section{Post Script}

The Constitution of Nepal 2015 (Schedule 8) provisions local governments to be responsible for school education management. However, because of the absence of elected local representatives, the implementation of the constitution has become a stumbling block. The local and the legislative elections of 2017 have filled the vacuum and thence 
Constitutional provisions have become active. In this new scenario, it will be interesting to see how the local bodies function in regards to the authority given to them. Though the context of the present study depicts my observation noted in the pre-constitution implementation phase, new insights in the post-constitution implementation is a subject of investigation.

\section{Notes}

${ }^{1}$ To maintain the anonymity, I have used pseudo name of the schools.

${ }^{2}$ Transfer of responsibility and resources from public to private sector institution.

${ }^{3}$ Adoption of market principles and mechanism.

${ }^{4}$ The period of time (1951-1960) in the history of Nepal, which had witnessed unitary partyless Panchayat system, when the then King Mahendra had sacked 'democratically', elected government in 1961.

${ }^{5}$ The data for this study was collected in February and March, 2017.

${ }^{6}$ Conflict was between the Communist Party of Nepal (Maoist) and the government between 19962006 which claimed more than 12000 lives.

\section{References}

Ambrosio, J. (2013). Changing the subject: Neoliberalism and accountability in public education. Education Studies: A Journal of the American Educational Studies Association, 49(4), 316-333.

Apple, M. (2000). Between neoliberalism and neoconservatism: Education and conservatism in a global context. In N. Burbules \& C. A. Torres (Eds.), Globalization and education - Critical perspective (pp. 57-78). New York, NY: Routledge.

Artz, L., \& Murphy, B. O. (2000). Cultural hegemony in the United States. Thousand Oaks, CA: Sage.

Bhatta, P. (2009). Improving schools through decentralization: Observations from Nepal's primary education. In P. Bhatta (Ed.), Education in Nepal: Problems reforms and social change (pp.151-186). Kathmandu, Nepal: Martin Chautari.

Carney, S., \& Bista, M. (2009). Community schooling in Nepal: A genealogy of education reform since 1990. Comparative Education Review, 53(2), 189-211. doi:10.1086/597394

Carney, S., Bista, M., \& Agergaard, J. (2007). Empowering the local through education? Exploring community-managed schooling in Nepal. Oxford Review of Education, 33(5), 611-628. doi:10.1080/03054980701476253
Coleman, J. (1988). Social capital in the creation of human capital. American Journal of Sociology, 94, S95-S120. Retrieved from http://www.jstor.org/stable/2780243

Darrow, M., \& Tomas, A. (2005). Power, capture, and conflict: A call for human rights accountability in development cooperation. Human Rights Quarterly, 27(2), 471-538.

Department of Education. (2008). Social audit implementation directives. Kathmandu, Nepal: Author.

Dutta, D. (2009). Elite capture and corruption: Concepts and definitions. New Delhi, India: NCAER.

Eaton, K., Kaiser, K., \& Smoke, P. (2010). The political economy of decentralization reforms: Implications for aid effectiveness. Washington, DC: The World Bank.

Edwards, R. M. (2011). Disconnect and capture of education decentralisation reforms in Nepal: Implication for community involvement in schooling. Globalisation, Societies and Education, 9(1), 67-84. doi:10.1080/14767724.2010.513532

Fiske, E. B. (1996). Decentralization of education: Politics and consensus. Washington, DC: The World Bank.

Fox, J. (1994). The difficult transition from clientelism to citizenship: Lessons from Mexico. World Politics, 46(2),84-151.

Higley, J. (2010). Elite theory and elites. In K. T. Leicht \& J. C. Jenkins (Eds.), Handbook of politics: State and society in global perspective (pp. 161-176). New York, NY: Springer.

His Majesty's Government of Nepal. (2002). The education act (7th amendment). Kathmandu, Nepal: Author.

His Majesty's Government of Nepal. (1999). The local-self governance act. Kathmandu, Nepal: Author.

Inbanathan, A. (2000). Power, patronage and accountability in the panchayats of Karnataka (Working Paper No. 68). Retrieved from http://www.isec.ac.in/Power_ patronage_and_accountability.pdf

Khanal, P. (2010). School decentralisation in Nepal: A disjuncture between macro-level advocacy and micro-level reality? Educational Research for Policy and Practice, 9(3), 145-158. doi:10.1007/s10671-010-9088-Z

López, M. (2013). Elite theory. Sociopeia.isa, 1-12. Retrieved from http://www.sagepub. net/isa/resources/pdf/elitetheory.pdf 
Macharia, K. (1997). Social and political dynamics of the informal economy in African cities: Nairobi and Harare. New York, NY: University Press of America.

Mattingly, D. (2016). Elite capture: How decentralization and informal institutions weaken property rights in China. World Politics, 68(3), 383-412.

Mok, K. H. (1999). Education and the market place in Hong Kong and mainland China. HigherEducation, 37, 133-158.

Musgrave, M. K., \& Wong, S. (2016). Towards a more nuanced theory of elite capture in development projects. The importance of Context and Theories of Power. Journal of Sustainable Development, 9(3), 87-103.

Newton, K. (1999). Social capital and democracy in modern Europe. In J. W. Deth., M. Maraffi., K. Newton., \& P. F. Whiteley (Eds.), Social capital and European democracy (pp. 3-24). London, England: Routledge.

Odera, L. C. (2013). The role of trust as an informal institution in the informal sector in Africa. Africa Development/Africa et Developpement, 38(3/4), 121-146.

Palaniswamy, N., \& Krishnan, N. (2012). Local politics, political institutions, and public resource allocation. Economic Development and Cultural Change, 60(3), 449-473.

Parajuli, M. N. (2007). People's participation in school governance? Realities of educational decentralization in Nepal. In H. Daun (Ed.), School decentralization in the context of globalizing governance (pp. 195-211). Dordrecht, The Netherlands: Springer.

Pareto, V. (1935). The mind and society. London, England: Jonathan Cape Ltd. Retrieved from https://ia800302.us.archive.org/35/items/mindandsocietyvo029378mbp/ mindandsocietyvo029378mbp.pdf

Prinsen, G., \& Titeca, K. (2008). Uganda's decentralised primary education: Musical chairs and inverted elite capture in school management committees. Public Administration and. Development, 28(2), 149-164.

Putnam, R. D. (1993). Making democracy work. Civic traditions in modern Italy. Princeton, NJ: Princeton University Press.

Putnam, R. D. (1995). Bowling alone: America's declining social capital. Journal of Democracy 6(1), 64-78.

Research Center for Education Innovation and Development. (2009). Community management schools: An innovative approach to school management. Kathmandu, Nepal: Author.
Tolofari, S. (2005). New public management and education. Policy Futures in Education, 3(1), 75-90.

Watson, K. (2000). Dependency vs. partnership: The paradoxes of educational aid and development in an age of globalisation. World Studies in Education, 1(2), 123-143.

Weiler, H. (1990). Comparative perspectives on educational decentralization: An exercise in contradiction? Educational Evaluation and Policy Analysis, 12(4), 433-448. Retrieved from http://www.jstor.org/stable/1164476

Yamokoski, A., \& Dubrow, J. (2008). How do elites define influence? Personality and respect as sources of social power. Sociological Focus, 41(4), 319-336. Retrieved from http://www.jstor.org/stable/20832377

Zajda, J., \& Gamage D. T. (2009). Decentralization and school-based management and quality. In J. Zajda \& D. T. Gamage (Eds.), Decentralisation, school-base management and quality (pp. 15-25). New York, NY: Springer.

Zajda. J. (2006). Decentralisation and privatisation in education: The role of the state. In J. Zajda (Ed.), Decentralisation and privatisation in education: The role of the state (pp. 3-27). Dordrecht, The Netherlands: Springer. 